This is an author manuscript that has been accepted for publication in International Journal of Systematic and Evolutionary Microbiology, copyright Society for General Microbiology, but has not been copy-edited, formatted or proofed. Cite this article as appearing in International Journal of Systematic and Evolutionary Microbiology. This version of the manuscript may not be duplicated or reproduced, other than for personal use or within the rule of 'Fair Use of Copyrighted Materials' (section 17, Title 17, US Code), without permission from the copyright owner, Society for General Microbiology. The Society for General Microbiology disclaims any responsibility or liability for errors or omissions in this version of the manuscript or in any version derived from it by any other parties. The final copy-edited, published article, which is the version of record, can be found at http://ijs.sgmjournals.org, and is freely available without a subscription 24 months after publication.

First published in: Int J Syst Evol Microbiol, 2009. 60(2) 271-274. doi:10.1099/ijs.0.012567-0

\title{
Citricoccus parietis sp. nov., isolated from a mould-colonized wall and emended description of Citricoccus alkalitolerans Li et al. 2005
}

\author{
Correspondence \\ Peter Kämpfer \\ peter.kaempfer@umwelt. \\ uni-giessen.de
}

\author{
Jenny Schäfer, ${ }^{1}$ Karin Martin ${ }^{2}$ and Peter Kämpfer ${ }^{1}$
${ }^{1}$ Institut für Angewandte Mikrobiologie, Justus-Liebig-Universität Giessen, D-35392 Giessen, Germany
${ }^{2}$ Leibniz-Institut für Naturstoff-Forschung und Infektionsbiologie e. V., Hans-Knöll-Institut, D-07745 Jena, Germany

\begin{abstract}
A Gram-positive, coccoid-shaped organism (strain 02-Je-010 ${ }^{\top}$ ), forming yellow-pigmented colonies was isolated from the wall of an indoor environment. On the basis of 16S rRNA gene sequence similarity studies, it was shown that strain $02-\mathrm{Je}-010^{\top}$ belongs to the genus Citricoccus with sequence similarities of $98.9 \%$ to Citricoccus alkalitolerans DSM $15665^{\top}$ and $98.6 \%$ to Citricoccus muralis DSM $14442^{\top}$. Cell-wall sugars were mannose and glucose. The diagnostic diamino acid of the peptidoglycan was lysine. The major menaquinones detected were MK-9( $\left.\mathrm{H}_{2}\right)$ and MK- $8\left(\mathrm{H}_{2}\right)$. The polar lipid profile consisted of the major lipids diphosphatidylglycerol, phosphatidylglycerol and phosphatidylinositol and moderate amounts of two unknown phospholipids and two unknown glycolipids. The fatty acid profile comprised major amounts of anteiso- $\mathrm{C}_{15: 0}$, anteiso- $\mathrm{C}_{17: 0}$ and iso- $\mathrm{C}_{15: 0}$. All these data supported the affiliation of strain 02$\mathrm{Je}-010^{\top}$ to the genus Citricoccus. The results of DNA-DNA hybridization and physiological and biochemical tests allowed genotypic and phenotypic differentiation of strain $02-\mathrm{Je}-010^{\top}$ from the two recognized Citricoccus species. For these reasons, strain $02-\mathrm{Je}-010^{\top}$ represents a novel species, for which the name Citricoccus parietis sp. nov. is proposed, with the type strain 02-Je$010^{\top}\left(=\right.$ CCUG $57388^{\top}=$ CCM $\left.7609^{\top}\right)$.
\end{abstract}

The genus Citricoccus, originally proposed by Altenburger et al. (2002) comprises the two species Citricoccus muralis, isolated from a medieval wall painting (Altenburger et al., 2002), and Citricoccus alkalitolerans, isolated from a desert soil sample collected in Egypt (Li et al., 2005). Both species were isolated from dry samples.

Strain $02-\mathrm{Je}-010^{\mathrm{T}}$ was enriched and recovered from a wall colonized with mould. After extraction of a $1 \mathrm{~g}$ material sample by shaking for $15 \mathrm{~min}$ in $10 \mathrm{ml} 0.9 \% \mathrm{NaCl}$ solution containing $0.01 \%(\mathrm{v} / \mathrm{v})$ Tween 80 , aliquots of this suspension were spread on plates containing organic medium M79 agar [containing $\left(\mathrm{l}^{-1}\right)$ : $10 \mathrm{~g}$ glucose, $10 \mathrm{~g}$ peptone (Bacto), $2 \mathrm{~g}$ casein hydrolysate, 2 g yeast extract, $6 \mathrm{~g} \mathrm{NaCl}$ and $15 \mathrm{~g}$ agar; $\mathrm{pH}$ 7.0]. The plates were incubated for 2 weeks at $28{ }^{\circ} \mathrm{C}$. The isolated strain was maintained on organic medium M79 and preserved at $-80{ }^{\circ} \mathrm{C}$ by mixing in a 1:1 ratio of well-grown cultures in organic medium M79 broth with glycerol preservation medium (Salser, 1978),

The GenBank/EMBL/DDBJ accession number for the $16 \mathrm{~S}$ rRNA gene sequence of strain $02-\mathrm{Je}-010^{\top}$ is $\mathrm{FM} 992367$.

A table showing the major fatty acid compositions of strain $02-\mathrm{Je}-010^{\top}$ and the type strains of species of the genus Citricoccus is available as supplementary material with the online version of this paper. containing (w/v): $1.26 \% \mathrm{~K}_{2} \mathrm{HPO}_{4}, 0.36 \% \mathrm{KH}_{2} \mathrm{PO}_{4}, 0.01 \%$ $\mathrm{MgSO}_{4} \cdot \mathrm{H}_{2} \mathrm{O}, 0.09 \%$ sodium citrate, $0.18 \%\left(\mathrm{NH}_{4}\right)_{2} \mathrm{SO}_{4}$ and $8.8 \%$ glycerol. Stock cultures of the isolates in liquid M79 supplemented with 5\% DMSO were additionally maintained in the vapour phase of liquid nitrogen. Morphological properties, Gram-staining and cell morphology were observed microscopically as described by Kämpfer \& Kroppenstedt (2004). Isolation of the DNA was performed with a commercialized DNA extraction kit (GenElute Plant Genomic DNA kit; Sigma) after disruption of cells by using a $1 \mathrm{~min}$ bead-beating step with $1 \mathrm{~g} 0.1 \mathrm{~mm}$ $\varnothing$ Zirconia beads at maximum speed.

Multiple sequence alignment and analysis of the data were performed using the software package MEGA (Molecular Evolutionary Genetics Analysis) version 4 (Tamura et al., 2007). Genetic distances were calculated using the Kimura2 model. Clustering by using the neighbour-joining (Fig. 1) and maximum-parsimony (results not shown) methods were performed after bootstrap analysis based on 1000 replications. The $16 \mathrm{~S}$ rRNA gene sequence of strain 02-Je$010^{\mathrm{T}}$ was a continuous stretch of $1415 \mathrm{bp}$.

Sequence similarity calculations after the neighbour-joining analysis indicated that the closest relatives of strain 


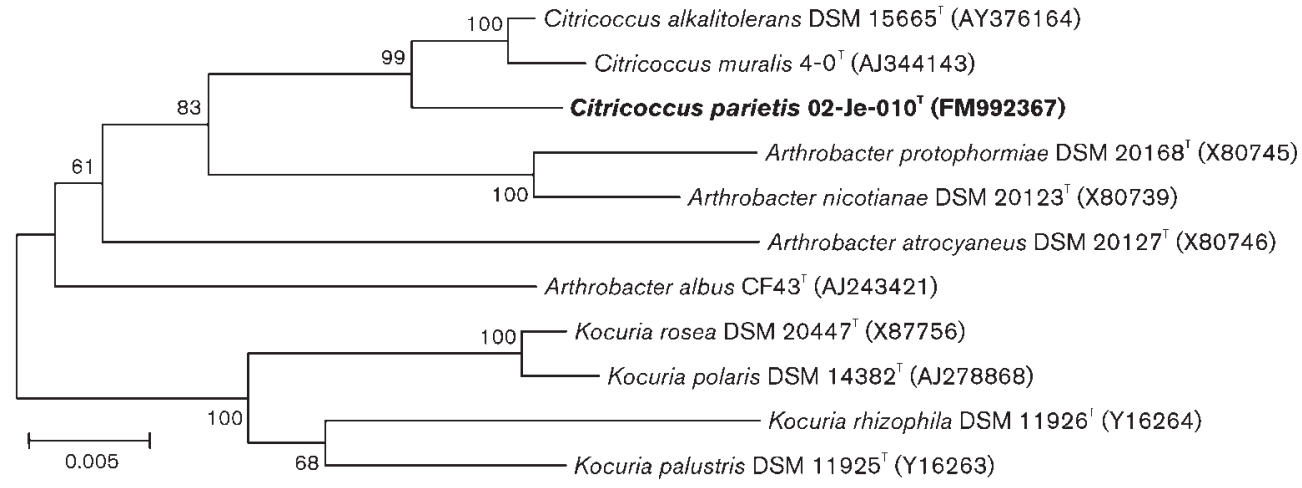

Fig. 1. Phylogenetic analysis based on $16 \mathrm{~S}$ rRNA gene sequences available from the European Molecular Biology Laboratory database (accession numbers are given in parentheses). Multiple alignment, distances (distance options according to the Kimura-2 model) and clustering with the neighbour-joining method were performed by using the software package MEGA (Molecular Evolutionary Genetics Analysis) version 4 (Tamura et al., 2007). Percentage bootstrap values based on 1000 replications are given at branch points. Bar, 0.005 substitutions per nucleotide position.

02-Je- $010^{\mathrm{T}}$ were C. alkalitolerans DSM $15665^{\mathrm{T}}(98.9 \%)$, and C. muralis DSM $14442^{\mathrm{T}}(98.6 \%)$.

Bacterial biomass of the isolate for chemotaxonomic investigations was prepared by cultivating strain 02-Je$010^{\mathrm{T}}$ for $24-48 \mathrm{~h}$ in shake flasks in liquid organic medium M79 at 180 r.p.m. at $28^{\circ} \mathrm{C}$, except for the fatty acid analyses where cells were grown in tryptic soy broth.

Standard paper chromatography, HPLC and TLC procedures were used to determine the quinone system (Collins et al., 1977; Groth et al., 1996), whole-organism sugars (Becker et al., 1965) and polar lipids (Minnikin et al., 1979). Analysis of the amino acids in peptidoglycan hydrolysates was carried out according to Schleifer \& Kandler (1972) and as described by Groth et al. (1996). Fatty acid analysis was performed according to Kämpfer \& Kroppenstedt (1996). The diagnostic diamino acid of the peptidoglycan was lysine together with glutamic acid and glycine (variation $\mathrm{A} 4 \alpha$ ); whole-organism hydrolysates contained sugars composed of mannose and glucose.

Strain $02-\mathrm{Je}-010^{\mathrm{T}}$ exhibited a quinone system with the predominant menaquinones MK-9 $\left(\mathrm{H}_{2}\right)$ and MK-8 $\left(\mathrm{H}_{2}\right)(57$ and $25 \%$, respectively). Minor amounts of MK-9 (5\%) and MK-8 (3\%) were also detected.

The polar lipid profile was rather complex, consisting of seven components. The major lipids were diphosphatidylglycerol, phosphatidylglycerol and phosphatidylinositol; two unknown glycolipids and two unknown phospholipids were also present. Such a complex pattern of phospholipids, with the three major components and some unknown glyco- and phospholipids, was also described for $C$. muralis, whereas only two unknown glycolipids were found in C. alkalitolerans.

The fatty acid profile of strain $02-\mathrm{Je}-010^{\mathrm{T}}$ was very similar to those of C. alkalitolerans DSM $15665^{\mathrm{T}}$ and C. muralis DSM $14442^{\mathrm{T}}$ (Supplementary Table S1, available in IJSEM
Online). The chemotaxonomic markers of strain 02-Je$010^{\mathrm{T}}$ analysed were typical for the genus Citricoccus and supported the affiliation to this genus.

Strain 02-Je-010 ${ }^{\mathrm{T}}$ was grown on PYES medium (Altenburger et al., 2002) for the observation of growth at the following temperatures: $4,10,20,28,37,40$ and $45{ }^{\circ} \mathrm{C}$. Tolerance to $\mathrm{NaCl}$ and $\mathrm{pH}$ was determined as described by Altenburger et al. (2002). Growth was observed between 4 and $36{ }^{\circ} \mathrm{C}$ (but not above that temperature), at initial $\mathrm{pH}$ values $6.5-12.0$, with optimum growth at $\mathrm{pH} 8.0-9.0$, and in $1-10 \% \mathrm{NaCl}$.

Results of further comparative physiological characterization, using identical test conditions, are given in Table 1 and the species description, with methods as described previously (Kämpfer et al., 1991). DNA-DNA hybridization experiments were performed with strain $02-\mathrm{Je}-010^{\mathrm{T}}$ and C. alkalitolerans DSM $15665^{\mathrm{T}}$ and C. muralis DSM $14442^{\mathrm{T}}$ using the method described by Ziemke et al. (1998), with a minor variation in the nick translation step, where $2 \mu \mathrm{g}$ DNA was labelled during a $3 \mathrm{~h}$ incubation at $15{ }^{\circ} \mathrm{C}$.

We assumed a G $+\mathrm{C}$ content of the DNA of $68 \mathrm{~mol} \%$ for strain $02-\mathrm{Je}-010^{\mathrm{T}}$, as reported for C. muralis (Altenburger et al., 2002), in the DNA-DNA hybridization experiments. Because this $\mathrm{G}+\mathrm{C}$ content is about $4 \mathrm{~mol} \%$ higher than the value reported for C. alkalitolerans by $\mathrm{Li}$ et al. (2005), the $\mathrm{G}+\mathrm{C}$ content of the type strain of $C$. alkalitolerans was reanalysed at the DSMZ. The $\mathrm{G}+\mathrm{C}$ content of $C$. alkalitolerans DSM $15665^{\mathrm{T}}$ was $67.8 \mathrm{~mol} \%$.

Strain $02-\mathrm{Je}-010^{\mathrm{T}}$ showed relatively low DNA-DNA relatedness to $C$. alkalitolerans DSM $15665^{\mathrm{T}}(58.8 \%$, reciprocal $62.7 \%$ ) and C. muralis DSM $14442^{\mathrm{T}}(40.4 \%$, reciprocal $34.8 \%$ ). The observed physiological differences between these type strains (Table 1 ) clearly warrant the creation of a separate species. 
Table 1. Differential physiological characteristics of the type strains of Citricoccus species

Taxa: 1, strain 02-Je- $010^{\mathrm{T}}$ (Citricoccus parietis sp. nov.); 2, C. alkalitolerans DSM $15665^{\mathrm{T}}$; 3, C. muralis DSM $14442^{\mathrm{T}}$. All data are from this study. All strains were positive for utilization of cisaconitate, L-aspartate, citrate, fumarate, D-glucose ${ }^{\star}, 3$-hydroxybenzoate, DL-3-hydroxybutyrate, L-leucine, L-malate, D-maltitol, maltose*, D-mannose ${ }^{\star}, 2$-oxoglutarate, L-phenylacetate, L-proline, pyruvate, sucrose $^{*}$ and trehalose. All strains were negative for utilization of $N$ acetyl-D-galactosamine, $N$-acetyl-D-glucosamine ${ }^{\star}, \mathrm{D}$-adonitol, $\beta$-alanine ${ }^{*}$ L-arabinose $\dagger$, arbutin, cellobiose, D-fructose ${ }^{*}, \mathrm{D}$-galactose $\dagger$, myo-inositol, itaconate, D-mannitol, melibiose, mesaconate, L-ornithine, L-rhamnose, ribose $\dagger$, D-sorbitol, sucrose, L-tryptophan* and D-xylose. +, Positive; - , negative.

\begin{tabular}{|c|c|c|c|}
\hline Characteristic & 1 & 2 & 3 \\
\hline \multicolumn{4}{|l|}{ Assimilation of: } \\
\hline $\begin{array}{l}\text { Adipate, azelate, glutarate, L-histidine } e^{\star} \text {, putrescine, } \\
\text { suberate }\end{array}$ & + & & - \\
\hline $\begin{array}{l}\text { Acetate, } 4 \text {-hydroxybenzoate, L-phenylalanine, } \\
\text { propionate, L-serine }\end{array}$ & + & & + \\
\hline trans-Aconitate, L-alanine & - & + & - \\
\hline 4-Aminobutyrate & - & + & + \\
\hline DL-Lactate & + & - & + \\
\hline
\end{tabular}

${ }^{\star}$ Data congruent with those reported by Li et al. (2005) for C. alkalitolerans.

$\dagger$ Data not congruent with those reported by Li et al. (2005) for C. alkalitolerans.

\section{Description of Citricoccus parietis sp. nov.}

Citricoccus parietis (pa.ri'e.tis. L. gen. n. parietis of the wall of a house).

Coccoid cells, about $1.3 \mu \mathrm{m}$ in diameter. Gram-positive, and oxidase-positive and catalase-positive, showing an oxidative metabolism. Good growth occurs after 3 days incubation on tryptone soy agar, R2A agar and nutrient agar at $25-30{ }^{\circ} \mathrm{C}$. Colonies are yellow-pigmented, glistening, circular and opaque. Growth was observed at $4-36{ }^{\circ} \mathrm{C}$ (but not above that temperature), at $\mathrm{pH}$ 6.5-12.0, with optimum growth at $\mathrm{pH} 8.0-9.0$, and in $1-10 \% \mathrm{NaCl}$. The quinone system is composed of MK- $9\left(\mathrm{H}_{2}\right)$ and $\mathrm{MK}-8\left(\mathrm{H}_{2}\right)$.

The peptidoglycan is of the Lys-Glu-Gly type (variation $\mathrm{A} 4 \alpha$ ). The polar lipid profile consists of the major lipids diphosphatidylglycerol, phosphatidylglycerol and phosphatidylinositol, and two unknown glycolipids and two unknown phospholipids.

Major fatty acids are iso- and anteiso-branched fatty acids, such as anteiso- $\mathrm{C}_{15: 0}$, iso- $\mathrm{C}_{15: 0}$ and anteiso- $\mathrm{C}_{17: 0}$. Small amounts of iso- $\mathrm{C}_{16: 0}$, iso- $\mathrm{C}_{17: 0}$ and $\mathrm{C}_{16: 0}$ are also found. Carbon source utilization (including differential characteristics determined under identical conditions) is indicated in Table 1.
The type strain, $02-\mathrm{Je}-010^{\mathrm{T}} \quad\left(=\mathrm{CCUG} \quad 57388^{\mathrm{T}}=\mathrm{CCM}\right.$ $7609^{\mathrm{T}}$ ), was isolated in Jena, Germany, from the wall of a house colonized with mould.

\section{Emended description of Citricoccus alkalitolerans Li et al. 2005}

The description is that of Li et al. (2005) with the following emendations. The $\mathrm{G}+\mathrm{C}$ content of the DNA is $67.8 \mathrm{~mol} \%$ (HPLC method). Negative for the utilization of Dgalactose, D-arabinose and D-ribose on the basis of the method of Kämpfer et al. (1991). Results of some physiological tests are different based on the method of Kämpfer et al. (1991).

\section{Acknowledgements}

We are grateful to Carmen Schult, Christiane Weigel and Gundula Will for excellent technical assistance and Dr Elke Lang (DSMZ, Braunschweig, Germany) for kindly providing the type strain of $C$. alkalitolerans. We thank Dr Peter Schumann, DSMZ, Braunschweig, Germany for reanalysing the $\mathrm{G}+\mathrm{C}$ content of the DNA of $C$. alkalitolerans DSM $15665^{\mathrm{T}}$. We are grateful to Jean Euzéby for support with the nomenclature. This study was supported in part by the Federal Environment Agency (Umweltbundesamt), grant number FKZ 20562236.

\section{References}

Altenburger, P., Kämpfer, P., Schumann, P., Steiner, R., Lubitz, W. \& Busse, H.-J. (2002). Citricoccus muralis gen. nov., sp. nov., a novel actinobacterium isolated from a medieval wall painting. Int J Syst Evol Microbiol 52, 2095-2100.

Becker, B., Lechevalier, M. P. \& Lechevalier, H. A. (1965). Chemical composition of cell-wall preparations from strains of various formgenera of aerobic actinomycetes. Appl Microbiol 13, 236-243.

Collins, M. D., Pirouz, T., Goodfellow, M. \& Minnikin, D. E. (1977). Distribution of menaquinones in actinomycetes and corynebacteria. J Gen Microbiol 100, 221-230.

Groth, I., Schumann, P., Weiss, N., Martin, K. \& Rainey, F. A. (1996). Agrococcus jenensis gen. nov., sp. nov., a new genus of actinomycetes with diaminobutyric acid in the cell wall. Int J Syst Bacteriol 46, 234239.

Kämpfer, P. \& Kroppenstedt, R. M. (1996). Numerical analysis of fatty acid patterns of coryneform bacteria and related taxa. Can J Microbiol 42, 989-1005.

Kämpfer, P. \& Kroppenstedt, R. M. (2004). Pseudonocardia benzenivorans sp. nov. Int J Syst Evol Microbiol 54, 749-751.

Kämpfer, P., Steiof, M. \& Dott, W. (1991). Microbiological characterization of a fuel-oil contaminated site including numerical identification of heterotrophic water and soil bacteria. Microb Ecol 21, 227-251.

Li, W.-J., Chen, H.-H., Zhang, Y.-Q., Kim, C.-J., Park, D.-J., Lee, J.-C., Xu, L.-H. \& Jiang, C.-L. (2005). Citricoccus alkalitolerans sp. nov., a novel actinobacterium isolated from a desert soil in Egypt. Int J Syst Evol Microbiol 55, 87-90.

Minnikin, D. E., Collins, M. D. \& Goodfellow, M. (1979). Fatty acid and polar lipid composition in the classification of Cellulomonas, Oerskovia and related taxa. J Appl Bacteriol 47, 87-95. 
Salser, W. (1978). Cloning cDNA sequences: a general technique for propagating eukaryotic gene sequences in bacterial cells. In Genetic Engineering, pp. 53-81. Edited by A. M. Chakrabarty. West Palm Beach, FL: CRC Press, Inc.

Schleifer, K. H. \& Kandler, O. (1972). Peptidoglycan types of bacterial cell walls and their taxonomic implications. Bacteriol Rev 36, 407-477.
Tamura, K., Dudley, J., Nei, M. \& Kumar, S. (2007). MEGA4: Molecular Evolutionary Genetics Analysis (MEGA) software version 4.0. Mol Biol Evol 24, 1596-1599.

Ziemke, F., Höfle, M. G., Lalucat, J. \& Rosselló-Mora, R. (1998), Reclassification of Shewanella putrefaciens Owen's genomic group II as Shewanella baltica sp. nov. Int J Syst Bacteriol 48, 179-186. 